\title{
THE INFLUENCE OF INTERNAL AND EXTERNAL FACTORS ON CAPITAL STRUCTURE OF MANUFACTURING COMPANIES LISTED ON IDX IN 2016-2018
}

\section{Kevin Senjaya ${ }^{1 *}$ Lidya Agustina ${ }^{2}$}

1 Universitas Kristen Maranatha Bandung, Indonesia

2 Universitas Kristen Maranatha Bandung, Indonesia

*e-mail: senjayakevin@ymail.com

\begin{tabular}{ll}
\hline INFO ARTIKEL & ABSTRACT \\
\hline Histori Artikel : & This study aims to determine the internal and external \\
Tgl. Masuk : 25 Juli 2020 & factors of the company's capital structure. The variables in \\
Tgl. Diterima : 27 Agustus 2020 & this study consisted of profitability (X1), liquidity (X2), \\
Tersedia Online : 29 September 2020 & solvency (X3), tangibility (X4), sales growth (X5), inflation \\
\hline Keywords: & $(X 6)$, tax (X7), USD exchange rate (X8), and capital \\
Capital structure, internal factors, & structure (Y). The population in this study is the \\
external factors & manufacturing companies in the goods and consumption \\
& industry sector which are listed on the Indonesia Stock \\
& Exchange in 2016-2018. The sample in this study was \\
& chosen based on the purposive sampling method, resulting \\
& in 76 companies as much data. This study uses secondary \\
& data and the analysis technique used is multiple linear \\
& regression. The results of this study indicate that \\
profitability, solvency, tangibility, and tax affect the \\
company's capital structure, while liquidity, sales growth, \\
inflation, and the USD exchange rate do not affect the \\
company's capital structure
\end{tabular}

\section{PENDAHULUAN}

Perkembangan pasar modal di Indonesia beberapa tahun terakhir mengalami peningkatan yang cukup signifikan. Sepanjang tahun 2018 dan 2019, Indonesia menjadi negara dengan bursa yang mencatatkan IPO (Initiate Public Offering) terbanyak di kawasan ASEAN.

Hal tersebut menunjukan preferensi pendanaan perusahaan pada tahun-tahun sebelumnya cenderung berfokus kepada pendanaan eksternal melalui penerbitan saham (external equity financing). Keputusan pendanaan atau struktur modal perusahaan memiliki peran yang sangat penting bagi kelangsungan hidup perusahaan. Manajer keuangan harus mampu mengambil keputusan yang tepat dan cermat terhadap aktivitas pendanaan perusahaan. Karena jika manajer tidak tepat dalam memutuskan maka dapat menyebabkan perusahaan mengarah ke financial distress atau bahkan menuju kebangkrutan (Kaliman and Wibowo 2017:186).

Keputusan pendanaan atau struktur modal perusahaan dipengaruhi oleh faktor internal maupun faktor eksternal perusahaan. Dengan mengetahui faktor yang mempengaruhi struktur modal tersebut, dapat menjadi pertimbangan untuk investor dalam 
melakukan keputusan investasi pada suatu perusahaan. Misalnya, apabila terdapat faktor eksternal yang berpengaruh terhadap perusahaan, ketika fenomena tersebut terjadi, investor dapat memprediksi keputusan manajemen yang akan dilakukan manajer perusahaan terhadap struktur modalnya, sehingga dapat meminimalisir resiko investasi yang terjadi di masa yang akan datang.

\section{KERANGKA TEORITIS DAN PENGEMBANGAN HIPOTESIS}

\section{Trade Off Theory}

Menurut trade-off theory yang diungkapkan oleh Myers (2001), "Perusahaan akan berhutang sampai pada tingkat hutang tertentu, dimana penghematan pajak (tax shields) dari tambahan hutang sama dengan biaya kesulitan keuangan (financial distress)". Sedangkan (Yoshendy, Achsani, and Maulana 2016:50) menyatakan bahwa profitabilitas perusahaan yang tinggi, akan makin meningkatkan kapasitas perusahaan untuk mendapatkan pinjaman dari luar. Dengan pinjaman dari luar yang makin tinggi, perusahaan akan mendapat keuntungan pajak dari tax-shield, sehingga profitabilitas berhubungan positif dengan struktur modal. Menurut Gitman dan Zutter (2015: 579) dalam (Angelya and Arilyn 2017:314), keuntungan dari penggunaan hutang adalah pengurangan penghasilan kena pajak karena pembayaran bunga, yang berarti biaya hutang disubsidi oleh pemerintah, tetapi semakin meningkatnya proporsi hutang, maka semakin meningkat pula ketidakmampuan perusahaan untuk melakukan pembayaran hutang pada saat jatuh tempo dan akan mengalami kebangkrutan.

Struktur modal dipengaruhi oleh faktor-faktor internal maupun faktor-faktor eksternal. Hal ini sejalan dengan pernyataan faktor internal yang mempengaruhi struktur modal dikemukakan oleh (Budiono and Septiani 2017:121), yang menyatakan bahwa variabel mikroekonomi (internal) juga mempengaruhi struktur modal, diantaranya solvabilitas dan profitabilitas. Sedangkan (Budiono and Septiani 2017:120) menyatakan bahwa faktor yang mempengaruhi struktur modal adalah faktor lingkungan makroekonomi (eksternal). Bukti empirik terkait dengan pengaruh faktor lingkungan makroekonomi (eksternal) terhadap kebijakan struktur modal ditemukan oleh De Angelo dan Masulis (2006), bahwa inflasi secara teoritis dapat mendorong penggunaan utang karena semakin tinggi inflasi, bunga pinjaman secara relatif menjadi lebih murah

\section{Profitabilitas terhadap Struktur Modal}

Profitabilitas merupakan kemampuan perusahaan dalam menghasilkan laba. Profitabilitas mempengaruhi struktur modal perusahaan karena semakin besar laba ditahan semakin besar pula kecenderungan perusahaan untuk dapat memenuhi pendanaannya hanya melalui internal perusahaan. Profitabilitas terhadap pecking order theory menjelaskan bahwa semakin tinggi profitabilitas suatu perusahaan, maka akan cenderung tidak menggunakan hutang untuk membiayai investasinya (Nirmala et al. 2016). Sedangkan menurut Ratnawati (2001), Amidu (2007), Ghosh dan Ghosh (2009) dan Chowdury dan Chowdury (2010) dalam (Nirmala et al. 2016) menyatakan profitabilitas berpengaruh positif terhadap nilai perusahaan. Investor akan menganggap perusahaan yang mampu mengelola sumber daya perusahaan berarti dapat menghasilkan keuntungan yang tinggi dan diharapkan dapat meningkatkan nilai perusahaan.

\section{Solvabilitas terhadap Struktur Modal}

Solvabilitas menunjukan kemampuan perusahaan dalam melunasi kewajiban jangka panjang dalam periode tertentu. Menurut Hanafi dan Halim (2007, 77-88) dalam (Budiono and Septiani 2017), rasio solvabilitas digunakan untuk mengukur kemampuan perusahaan memenuhi 
kewajiban-kewajiban jangka panjangnya. Perusahaan dengan tingkat solvabilitas yang tinggi akan cenderung menggunakan pendanaan eksternal berupa hutang (fund financing) yang tinggi karena perusahaan dianggap memiliki sumber daya yang dibutuhkan untuk melunasi hutang jangka panjangnya pada saat jatuh tempo di masa mendatang.

\section{Likuiditas terhadap Struktur Modal}

Likuiditas menunjukan kemampuan perusahaan dalam melunasi kewajiban jangka pendeknya dalam suatu periode tertentu. Pecking Order Theory menyatakan bahwa tingkat likuiditas mempengaruhi suatu struktur modal perusahaan karena perusahaan dengan tingkat likuiditas tinggi cenderung memiliki dana internal yang besar sehingga perusahaan akan memenuhi pendanaan operasionalnya dengan pendanaan internal (internal financing) terlebih dahulu.

Perusahaan dengan tingkat likuiditas yang tinggi, cenderung akan melakukan pendanaan melalui pinjaman, karena perusahaan mampu membayar bunga dari pinjaman (Kaliman and Wibowo 2017). Hal ini sejalan dengan penelitian dari (Nita Septiani and Suaryana 2018), yang menyatakan bahwa perusahaan dengan kelebihan kas akan menggunakan kas tersebut untuk mengurangi utang. Hal ini menunjukkan perusahaan dengan likuiditas yang tinggi akan membuat perusahaan membayar utang-utangnya, sehingga akan berpengaruh pada menurunnya struktur modal.

\section{Tangibilitas terhadap Struktur Modal}

Tangibilitas perusahaan menunjukan seberapa besar persentase aktiva tetap terhadap total aktiva perusahaan. Tangibilitas merupakan salah satu faktor yang mempengaruhi struktur modal perusahaan. Perusahaan yang memiliki tingkat tangibilitas yang tinggi berarti memiliki aktiva tetap yang memadai untuk menjadi jaminan bagi perusahaan dalam melakukan keputusan pendanaan melalui pihak eksternal berupa hutang (fund financing). Hal ini sejalan dengan pernyataan Weston dan Copeland (1997) dalam (Maryanti 2016) yang menyatakan bahwa "Perusahaan yang mempunyai aktiva tetap jangka panjang lebih besar, maka perusahaan tersebut akan banyak menggunakan hutang jangka panjang, dengan harapan aktiva tersebut dapat digunakan untuk menutup tagihannya".

\section{Sales Growth terhadap Struktur Modal}

Sales growth merupakan tingkat kenaikan penjualan perusahaan pada suatu periode tertentu. Sales growth berpengaruh terhadap struktur modal perusahaan. Hal ini disebabkan oleh kebutuhan pendanaan yang cukup besar dalam mengimbangi pertumbuhan penjualan perusahaan. Seringkali pendanaan internal yang bersumber pada laba perusahaan kurang mencukupi, sehingga pendanaan dari pihak eksternal dibutuhkan. Menurut (Maryanti 2016), pada saat pertumbuhan penjualan meningkat, perusahaan akan mengambil utang agar dapat meningkatkan kapasitas produksi yang akan berdampak pada kenaikan penjualannya. Hal ini sejalan dengan pernyataan dalam (Nirmala et al. 2016) yang menyatakan pertumbuhan penjualan terhadap pecking order theory menjelaskan bahwa perusahaan yang memiliki pertumbuhan yang tinggi dari tahun ke tahun dikarenakan perputaran pendapatan yang cepat akibat memproduksi barang-barang yang hampir semua dikonsumsi oleh masyarakat, hal inilah yang mempengaruhi perusahaan mampu mencadangkan laba ditahan (retained earnings) sehingga akan cenderung menggunakan dana internal berupa laba ditahan untuk memenuhi kegiatannya sehingga akan memiliki tingkat rasio hutang jangka panjang yang rendah (Mahardhika dan Aisjah, 2014:8).

\section{Inflasi terhadap Struktur Modal}

Inflasi adalah suatu keadaan dimana harga barang secara umum mengalami kenaikan secara terus menerus atau terjadi penurunan nilai mata uang. Inflasi menjadi salah satu faktor eksternal yang mempengaruhi suatu struktur modal perusahaan. Menurut signalling theory, 
adanya tingkat inflasi yang tinggi akan mempengaruhi struktur modal perusahaan, hal ini dikarenakan perusahaan memerlukan sumber daya yang lebih besar untuk membiayai kegiatan produksi perusahaan, dimana harga bahan baku menjadi lebih tinggi karena adanya pengaruh inflasi tersebut sehingga perusahaan memerlukan pendanaan dari pihak eksternal berupa hutang (fund financing) dengan tujuan menutupi biaya produksi yang meningkat. Menurut De Angelo dan Masulis (2006) dalam (Budiono and Septiani 2017), inflasi secara teoritis dapat mendorong penggunaan utang karena semakin tinggi inflasi, bunga pinjaman secara relatif menjadi lebih murah. Hal ini menunjukan faktor eksternal inflasi dapat mempengaruhi struktur modal perusahaan.

\section{Kurs USD terhadap Rupiah terhadap Struktur Modal}

Menurut Sartono (2008:44) dalam (Budiono and Septiani 2017), nilai tukar (exchange rates) menunjukkan banyaknya unit mata uang yang dapat dibeli atau ditukar dengan satu satuan mata uang lain. Perusahaan yang dalam kegiatan operasionalnya melibatkan mata uang asing, maupun perusahaan multinasional yang melakukan ekspor dan impor tentu saja akan dipengaruhi oleh nilai tukar uang. Kurs USD terhadap rupiah berpengaruh terhadap struktur modal. Seperti yang dinyatakan dalam penelitian Perusahaan yang memiliki hutang dalam bentuk USD akan cenderung mengurangi hutangnya.

\section{Pajak terhadap Struktur Modal}

Pajak merupakan salah satu faktor eksternal yang berpengaruh terhadap struktur modal perusahaan. Hal ini dapat dijelaskan dengan menggunakan Modigliani and Miller (M\&M) Theory dengan preposisi Tax Case. Perusahaan yang menggunakan hutang (fund financing) sebagai sumber pendanaannya akan memiliki nilai yang lebih tinggi daripada perusahaan yang menggunakan alternatif lain sebagai sumber pendanaannya. Hal ini dikarenakan adanya penghematan pajak atau tax shield dalam bentuk bunga yang dapat dibebankan, sehingga dapat mengurangi pajak terutang perusahaan.

Sejalan dengan Modigliani and Miller (M\&M) Theory, adanya pengaruh Pajak terhadap struktur modal perusahaan juga dapat dijelaskan melalui Trade-off Theory, yang menyatakan bahwa perusahaan akan menerima perlindungan dari sisi pajak dengan menggunakan utang yang diperoleh dari pembayaran beban bunga kepada kreditur. Bunga pinjaman merupakan beban yang dapat digunakan untuk mengurangi pajak yang harus dikeluarkan perusahaan (Budiono and Septiani 2017). Hal ini berarti Pajak yang tinggi akan membuat perusahaan memanfaatkan pengurangan pajak terutangnya dengan melakukan keputusan pendanaan pinjaman (fund financing), dengan demikian besarnya pajak terutang yang tinggi dapat berkurang sebagai akibat dari adanya beban bunga pinjaman. Pernyataan ini sejalan dengan (Brigham dan Houston, 2011:40) dalam (Budiono and Septiani 2017), yaitu "Semakin tinggi Pajak perusahaan, maka semakin besar manfaat penggunaan utang sehingga dapat mengoptimalkan struktur modal".

\section{METODOLOGI PENELITIAN}

\section{Objek dan Subjek Penelitian}

Objek dalam penelitian ini sebagai variabel terikat (dependent variable) adalah Struktur Modal perusahaan manufaktur yang terdaftar di BEI (Bursa Efek Indonesia) selama periode 20162018. Sedangkan objek penelitian yang menjadi variabel bebas (independent variables) adalah Profitabilitas, Likuiditas, Solvabilitas, Tangibilitas, Sales Growth, Inflasi, Kurs USD terhadap Rupiah, dan Pajak perusahaan manufaktur yang terdaftar di BEl selama periode 20162018. Sedangkan subjek dalam penelitian ini adalah organisasi atau perusahaan manufaktur yang terdaftar di BEI (Bursa 
Efek Indonesia) selama periode 20162018.

\section{Jenis Penelitian}

Jenis penelitian ini adalah Causal Explanatory. Metode ini mengidentifikasi fakta atau peristiwa tersebut sebagai variabel yang dipengaruhi (variabel dependen) dan melakukan penyelidikan terhadap variabel-variabel yang mempengaruhi (variabel independen) (Indriantoro dan Supomo, 2012) dalam (Budiono and Septiani 2017:122). Sedangkan menurut Cooper \& Schindler dalam Hartono (2013:13), penelitian explanatory adalah riset yang mencoba menjelaskan fenomena yang ada. Dengan demikian, causal explanatory merupakan penelitian yang menjelaskan hubungan sebab-akibat antara variabel dependen dan variabel independen berdasakan hipotesis yang telah dirumuskan dan menjelaskan fenomena penelitian.

\section{Populasi dan Sampel Penelitian}

Populasi dalam penelitian ini adalah perusahaan manufaktur yang terdaftar di Bursa Efek Indonesia (BEI) pada tahun 2019. Jumlah populasi dalam penelitian ini adalah 180 perusahaan.

Sedangkan pengambilan sample dalam penelitian ini menggunakan judgment sampling dengan kriteria suatu pertimbangan tertentu. Kriteria sampel dalam penelitian ini adalah sebagai berikut:

1. Perusahaan manufaktur yang terdaftar di Bursa Efek Indonesia selama periode 2016-2018.

2. Perusahaan manufaktur yang mempublikasikan laporan keuangan yang telah di audit pada Bursa Efek Indonesia (BEI) secara berturut-turut dan lengkap dinyatakan dalam mata uang rupiah selama periode 2016-2018.

3. Perusahaan manufaktur yang tidak mengalami kerugian selama tahun 20162018.

Melihat dari kriteria yang telah dipaparkan diatas, maka jumlah perusahaan yang memenuhi ketiga kriteria adalah sebanyak 77 perusahaan.

\section{Variabel dan Definisi Operasional}

Profitabilitas menunjukkan kemampuan perusahaan dalam menghasilkan laba

$$
R O A=\frac{\text { Laba Operasi }}{\text { Total Aset }}
$$

Likuiditas menunjukan kemampuan perusahaan untuk membayar semua kewajiban finansial jangka pendek

$$
L I Q=\frac{\text { Current Assets }}{\text { Current Liabilities }}
$$

Solvabilitas merupakan kemampuan perusahaan memenuhi kewajibankewajiban jangka panjangnya.

$$
D A R=\frac{\text { Total Liabilities }}{\text { Total Asset }}
$$

Tangibilitas merupakan pengukuran persentase aset tetap terhadap total aset perusahaan

$$
T A N G=\frac{\text { Total Fixed Assets }}{\text { Total Assets }}
$$

Sales Growth merupakan perbandingan penjualan tahun ke-t setelah dikurangi penjualan periode sebelumnya

$$
S G=\frac{\text { Netsalest }- \text { Netsalest }-1}{\text { Netsalest }-1} \times 100 \%
$$

Inflasi merupakan naiknya indeks harga konsumen secara terus-menerus

$$
\text { Inflasi }=\frac{I H K t-I H K t-1}{I H K t-1} \times 100 \%
$$

Nilai tukar (exchange rates) menunjukkan tingkat mata uang yang dapat dibeli dengan mata uang lain

$$
K U R S=\frac{\text { Kurst }- \text { Kurst }-1}{\text { Kurst }-1}
$$

Pajak yang dibayarkan oleh perusahaan pada periode tertentu

$$
T A X=\frac{E B T-E A T}{E B T} \times 100 \%
$$

HASIL DAN PEMBAHASAN 
Data penelitian diolah menggunakan aplilkasi SPSS. Sebelum melakukan pengujian hipotesis, langkah yang terlebih dahulu dilakukan adalah menguji apakah model regresi memiliki model yang baik atau tidak melalui uji asumsi klasik.

\section{Uji Asumsi Klasik}

Uji normalitas dilakukan dengan dengan menggunakan analisis statistik (OneSample Kolmogorov Smirnov Test). Dari hasil pengujian, ditunjukkan bahwa nilai uji Kolmogorov-Smirnov (Asymp. Sig (2tailed)) sebesar 0.077. Nilai uji Kolmogorov Smirnov sebesar 0.077 melebihi nilai signifikansi penelitian, yaitu $5 \%$. Hal tersebut menunjukkan bahwa data sudah berdistribusi normal.

Uji Multikolinearitas dilakukan dengan menggunakan metode Collinearity Diagnostic. Hasil pengujian menunjukkan bahwa tidak ada variabel bebas yang memiliki nilai Tolerance lebih dari 0,10 . Hasil perhitungan VIF juga menunjukkan bahwa tidak ada variabel bebas yang memiliki nilai VIF lebih dari 10. Oleh karena itu dapat disimpulkan bahwa tidak ada multikorelasi antara variabel dalam model regresi, atau dengan kata lain, data terbebas dari multikolinearitas.

Uji autokorelasi dilakukan dengan metode Runs Test. Hasil pengujian autokorelasi dapat ditunjukan dari nilai Asymp. Sig yang lebih besar dari taraf nyata $(\alpha)$ yaitu sebesar .052. Hal tersebut menunjukan bahwa data penelitian terbebas dari gejala autokorelasi.

Uji heteroskidastisitas dilakukan dengan menggunakan Uji Glejser. hasil uji Heterokedastisitas dengan metode Glejser dapat dilihat dari nilai Sig. yang tersaji dalam tabel. Nilai Sig. ROA, CR, DAR, TAN, SG, TAX, INFLASI, dan KURS sudah melebihi tingkat signifikansi $5 \%$ $(0,05)$. Hal ini mengindikasikan tidak ada hubungan antara variabel bebas dengan nilai mutlak residual sehingga menunjukkan tidak adanya masalah heteroskedastisitas dalam model regresi.
Dengan kata lain, data sudah terbebas dari heterokedastisitas dan bersifat homokedastisitas.

\section{Pengujian Hipotesis}

Uji statistik F, Menurut Ghozali (2011:68) menunjukkan apakah semua variabel bebas yang dimaksudkan dalam model mempunyai pengaruh secara simultan terhadap variabel dependen. Pengujian dilakukan dengan membandingkan Sig. dengan significance level. Dalam penelitian ini, tingkat signifikansi yang digunakan adalah $5 \%(\alpha=0,05)$.

\section{Tabel I Hasil Uji F}

Tabel I Hasil Pengujian Simultan (Uji F) menunjukkan hasil Sig. sebesar $0.000 \leq$ 0,05 , sehingga $H_{0}$ ditolak. Dengan demikian maka $\mathrm{H}_{1}$ diterima Jadi paling sedikit terdapat satu variabel bebas (Profitabilitas (ROA), Likuiditas (CR), Solvabilitas (DAR), Tangibilitas, Sales Growth, Pajak, Inflasi, dan Kurs) yang mempengaruhi Struktur Modal

\begin{tabular}{|l|r|c|c|}
\hline \multicolumn{1}{|c|}{ Model } & \multicolumn{1}{c|}{ df } & F & Sig \\
\hline Regression & 8 & 206.037 & $.000_{\mathrm{a}}$ \\
\hline Residual & 132 & & \\
\hline Total & 140 & & \\
\hline
\end{tabular}

Perusahaan. Dengan kata lain, faktor internal; Profitabilitas (ROA), Likuiditas (CR), Solvabilitas (DAR), Tangibilitas dan Sales Growth, serta faktor eksternal; Inflasi, Kurs USD terhadap Rupiah, dan Pajak mempengaruhi Struktur Modal Perusahaan secara simultan.

Pengujian Statistik Parsial (Uji t) menurut Ghozali (2011:64) pada dasarnya menunjukkan seberapa jauh pengaruh satu variabel independen secara individual dalam menerangkan variabel dependen. Sedangkan menurut Suliyanto (2009:188), uji t dilakukan untuk menguji hipotesis dalam satu sampel, apakah satu nilai yang merupakan hipotesis yang kita ajukan 
berbeda secara nyata dengan nilai ratarata dalam sebuah sampel.

Tabel II Hasil Uji t

\begin{tabular}{|l|r|r|r|}
\hline $\begin{array}{c}\text { Variable } \\
\text { Independen }\end{array}$ & \multicolumn{1}{c|}{ B } & \multicolumn{1}{c|}{ T } & \multicolumn{1}{c|}{ Sig } \\
\hline ROA & -.081 & -2.577 & .011 \\
\hline CR & .065 & 1.654 & .101 \\
\hline DAR & 1.026 & 27.817 & .000 \\
\hline TAN & -.068 & -2.484 & .014 \\
\hline SG & .021 & .800 & .425 \\
\hline TAX & -.099 & -3.096 & .002 \\
\hline Inflasi & .002 & .077 & .939 \\
\hline KURS & -.009 & -.303 & .762 \\
\hline
\end{tabular}

Dari hasil pengujian pada tabel II, didapatkan bahwa variabel bebas profitabilitas (ROA), Solvabilitas (DAR), Tangibilitas, dan Pajak (TAX) berpengaruh terhadap struktur modal perusahaan, ditunjukan dengan nilai Sig. $\leq \alpha(5 \%)$, sedangkan variabel bebas Likuiditas (CR), Sales Growth, Inflasi, dan Kurs tidak berpengaruh terhadap struktur modal perusahaan.

Tabel III Koefisien Determinasi

\begin{tabular}{|c|c|c|r|}
\hline Model & $\mathrm{R}$ & $\mathrm{R}^{2}$ & Adjusted $\mathrm{R}^{2}$ \\
\hline 1 & $.962 \mathrm{a}$ & .926 & .921 \\
\hline
\end{tabular}

Hasil pengujian menunjukkan Adjusted $\mathrm{R}$ Square sebesar 0.921. Hal ini berarti bahwa $92,1 \%$ indeks Struktur Modal perusahaan dapat dijelaskan atau dipengaruhi oleh faktor internal; Profitabilitas (ROA), Likuiditas (CR), Solvabilitas (DAR), Tangibilitas dan Sales Growth, serta faktor eksternal; Inflasi, Kurs USD terhadap Rupiah, dan Pajak, sedangkan sisanya, 7,9\% (100\% - 92,1\%) dipengaruhi oleh variabel lain.

Sedangkan nilai $R$ sebesar 0.962 menunjukkan bahwa koefisien korelasi sebesar 96,2\%. Dari nilai ini dapat disimpulkan bahwa hubungan antara faktor internal; Profitabilitas (ROA), Likuiditas (CR), Solvabilitas (DAR), Tangibilitas dan Sales Growth, serta faktor eksternal; Inflasi, Kurs USD terhadap Rupiah, dan Pajak dengan Struktur Modal perusahaan adalah searah dan memiliki keeratan yang sangat kuat.

\section{Pembahasan}

\section{Pengaruh Profitabilitas Terhadap Struktur Modal}

Berdasarkan hasil penelitian, didapatkan hasil bahwa profitabilitas (ROA) berpengaruh negatif terhadap struktur modal perusahaan. Profitabilitas merupakan kemampuan perusahaan dalam menghasilkan laba dengan menggunakan aset yang dimiliki sebagai sumber daya. Menurut Trade-Off theory, perusahaan dengan tingkat profitabilitas yang tinggi akan cenderung meningkatkan tingkat hutangnya. Hal ini dikarenakan, perusahaan merasa memiliki sumber daya yang cukup untuk melunasi hutanghutangnya di masa yang akan datang dengan tingkat kemampuan melaba yang tinggi. Namun, menurut pecking order theory, perusahaan dengan profitabilitas yang tinggi akan cenderung memiliki tingkat hutang yang rendah. Hal ini dikarenakan, perusahaan dengan kemampuan melaba yang tinggi, akan merasa mampu untuk mendanai biayabiaya operasional perusahaan melalui sumber internalnya saja.

Hasil penelitian ini sejalan dengan penelitian yang dilakukan oleh Budiono and Septiani (2017); Lia Erosvitha and Wirawati (2016); Angelya and Arilyn (2017), Nirmala, Moeljadi, and Andarwati (2016), Ariyani, Pangestuti, and Raharjo (2019), dan Manajemen et al. (2019) yang menyatakan bahwa terdapat pengaruh negatif dan signifikan antara profitabilitas dan struktur modal perusahaan.

\section{Pengaruh Likuiditas Terhadap Struktur Modal}

Berdasarkan hasil penelitian, didapatkan hasil bahwa likuiditas (Current Ratio) tidak berpengaruh terhadap struktur modal perusahaan. Perusahaan dengan likuiditas yang tinggi belum tentu akan meningkatkan atau mengurangi sumber pendanaanya melalui hutang. Hal ini disebabkan karena likuiditas yang tinggi hanya menggambarkan kemampuan perusahaan dalam melunasi hutang 
jangka pendek dengan menggunakan aktiva lancar yang dimiliki perusahaan. Sedangkan untuk pendanaan perusahaan yang lebih besar, perusahaan cenderung akan menggunakan hutang jangka panjang yang tidak dapat digambarkan melalui likuiditas perusahaan. Tingkat likuiditas yang tinggi juga belum tentu akan meningkatkan maupun mengurangi modal dari investor. Hal ini dikarenakan likuiditas hanya merupakan satu dari berbagai faktor yang dapat meningkatkan kepercayaan investor untuk menanamkan modal kepada perusahaan yang akan berimplikasi pada peningkatan modal perusahaan.

Hasil penelitian ini sejalan dengan penelitian yang dilakukan oleh Yoshendy, Achsani, and Maulana (2016); dan Kaliman and Wibowo (2017) yang menyatakan bahwa likuiditas tidak berpengaruh terhadap struktur modal perusahan.

\section{Pengaruh Solvabilitas Terhadap Struktur Modal}

Berdasarkan hasil penelitian didapatkan hasil bahwa solvabilitas (Debt to Asset ratio) berpengaruh positif terhadap struktur modal perusahaan. Secara teoritis, perusahaan dengan tingkat hutang yang tinggi dibandingkan asetnya akan meningkatkan total hutang keseluruhan perusahaan yang mengakibatkan meningkatnya komposisi hutang dibandingkan dengan modal pada struktur pendanaannya. Perusahaan dengan tingkat hutang yang tinggi dibandingkan asetnya juga akan berpengaruh positif terhadap struktur modal perusahaan karena akan mengakibatkan rendahnya minat investor dalam menanamkan modal terhadap perusahaan.

Investor sangat memperhatikan kondisi keuangan perusahaan, semakin tinggi tingkat hutang dibandingkan aset perusahaan, semakin tinggi resiko perusahaan mengalami gagal bayar, atau kegagalan dalam melunasi hutangnya pada saat jatuh tempo. Tingginya resiko tersebut menyebabkan rendahnya sumber pendanaan perusahaan yang berasal dari investor berupa modal, sehingga berimplikasi pada meningkatnya struktur modal perusahaan. Hasil ini sesuai dengan hipotesis penelitian yang menyatakan bahwa solvabilitas mempunyai pengaruh negatif terhadap struktur modal perusahaan.

Hasil penelitian ini sejalan dengan penelitian yang dilakukan oleh Budiono and Septiani (2017) yang menyatakan bahwa solvabilitas berpengaruh positif dan signifikan terhadap struktur modal perusahaan.

\section{Tangibilitas Terhadap Struktur Modal}

Berdasarkan hasil penelitian, didapatkan hasil bahwa tangibilitas berpengaruh negatif terhadap struktur modal perusahaan. Perusahaan dengan struktur aset yang tinggi akan berpengaruh negatif terhadap struktur modal perusahaan. Hal ini dikarenakan, tangibilitas atau suatu struktur aktiva perusahaan berhubungan dengan tingkat aktiva tetap dan investasi yang dibentuk oleh perusahaan. Perusahaan yang sebagian besar dari modalnya tertanam pada aset tetap akan mengutamakan pemenuhan modalnya dari modal permanen, yaitu modal sendiri sedangkan hutangnya hanya pelengkap.

Hasil penelitian ini sejalan dengan penelitian yang dilakukan oleh Angelya and Arilyn (2017), Nita Septiani and Suaryana (2018), dan Yoshendy et al. (2016) yang menyatakan bahwa tangibilitas mempunyai pengaruh negatif terhadap struktur modal perusahaan.

\section{Pengaruh Sales Growth Terhadap Struktur Modal}

Berdasarkan hasil penelitian, didapatkan hasil bahwa sales growth tidak berpengaruh secara signifikan terhadap struktur modal perusahaan. Perusahaan dengan pertumbuhan penjualan tidak berpengaruh terhadap komposisi tertentu struktur modalnya. Pertumbuhan perusahaan dari segi penjualan kurang dapat memberikan pengaruh terhadap struktur pendanaannya. Pertumbuhan penjualan hanya menggambarkan adanya peningkatan dari segi penjualan, dimana peningkatan tersebut seringkali diiringi dengan peningkatan biaya yang 
dibutuhkan perusahaan untuk dapat beroperasi. Biaya-biaya yang dibutuhkan perusahaan dalam menghadapi pertumbuhan penjualan dapat diambil dari berbagai sumber. Baik dari aktiva atau pendanaan internalnya, dengan menggunakan pendanaan eksternal berupa hutang, maupun dengan pendanaan eksternal berupa penerbitan saham.

Hasil penelitian ini sejalan dengan penelitian yang dilakukan oleh Ariyani et al. (2019) dan Maryanti (2016) yang menyatakan bahwa pertumbuhan penjualan tidak berpengaruh terhadap struktur modal perusahaan.

\section{Pengaruh Pajak Terhadap Struktur Modal}

Berdasarkan hasil penelitian
didapatkan hasil bahwa paja
berpengaruh negatif terhadap struktur modal perusahaan. Pajak merupakan salah satu faktor penentu komposisi atau struktur pendanaan suatu perusahaan. Menurut Trade-Off theory, perusahaan akan menerima perlindungan dari sisi pajak dengan menggunakan hutang yang diperoleh dari pembayaran beban bunga kepada kreditur. Bunga pinjaman merupakan beban yang dapat dikurangkan, dengan tujuan mengurangi beban pajak keseluruhan perusahaan. Namun dengan adanya tujuan perusahaan dalam penghematan pajak, perusahaan belum tentu meningkatkan tingkat hutangnya hanya semata-mata untuk mencapai tujuan penghematan pajak tersebut, melainkan banyak faktor yang harus dipertimbangkan perusahaan ketika meningkatkan tingkat hutangnya seperti likuiditas dan solvabilitas. Tujuan perusahaan dalam mengurangi beban pajak dengan cara meningkatkan tingkat hutang tanpa memperhatikan variabel yang lain, dapat meningkatkan resiko perusahaan mengalami gagal bayar, yaitu kegagalan perusahaan dalam membayar kewajiban keuangannya pada saat jatuh tempo.

Adanya hubungan negatif antara pajak dan struktur modal perusahaan, dikarenakan tingginya aset tetap yang dimiliki sebagian besar perusahaan manufaktur, ditandai dengan adanya tingkat tangibilitas perusahaan yang tinggi. Semakin tinggi aset tetap yang diinvestasikan maka jumlah depresiasi akan semakin tinggi dan semakin besar manfaat dari pengurangan pajak yang diterima, sehingga sumber dana internal yang dimiliki semakin besar, yang berakibat pada rendahnya kebutuhan akan dana eksternal berupa utang.

\section{Pengaruh Inflasi Terhadap Struktur Modal}

Berdasarkan hasil penelitian, didapatkan hasil bahwa Inflasi tidak berpengaruh terhadap struktur modal perusahaan. Inflasi merupakan proses kecenderungan kenaikan harga-harga umum barang dan jasa secara terus menerus, dimana inflasi sebagai faktor eksternal yang berubah tiap periodenya, dimana dapat menyebabkan adanya perubahan dalam keputusan pendanaan perusahaan.

Menurut Signalling Theory, Semakin tinggi tingkat inflasi suatu negara maka akan mengakibatkan naiknya biaya bahan baku yang diperlukan perusahaan manufaktur. Kenaikan biaya bahan baku akan menyebabkan kenaikan pada biaya operasional perusahaan sehingga perusahaan memerlukan biaya yang lebih besar. Ketika dana internal perusahaan tidak mencukupi, maka salah satu upaya mendapatkan dana yang besar adalah dengan melakukan hutang, sehingga mengakibatkan peningkatan terhadap struktur modal perusahaan.

Dalam penelitian ini, faktor eksternal inflasi tidak berpengaruh secara signifikan terhadap struktur modal perusahaan manufaktur karena tingkat inflasi dari tahun ke tahun di Indonesia tidak menunjukan fluktuasi yang besar. Sehingga tidak memiliki dampak yang cukup untuk membuat perusahaan mengubah struktur pendanaannya. Tingkat inflasi yang cenderung stabil membuat harga-harga umum barang dan jasa tetap stabil, sehingga perusahaan 
manufaktur tidak memerlukan tambahan dana yang besar dalam menghadapi kenaikan bahan baku yang dipicu oleh inflasi tersebut.

Hasil penelitian ini sejalan dengan penelitian yang dilakukan oleh Budiono and Septiani (2017); dan Manajemen et al. (2019) yang menyatakan bahwa inflasi berpengaruh positif namun tidak signifikan terhadap struktur modal perusahaan.

\section{Pengaruh Kurs USD Terhadap Struktur Modal}

Berdasarkan hasil penelitian, didapatkan hasil bahwa Kurs USD tidak berpengaruh terhadap struktur modal perusahaan. Perusahaan yang dalam kegiatan operasionalnya melibatkan mata uang asing, maupun perusahaan multinasional yang melakukan ekspor dan impor tentu saja akan dipengaruhi oleh nilai tukar uang. Dengan adanya kenaikan (apresiasi) atau penurunan (depresiasi) nilai tukar mata uang USD terhadap rupiah, dapat mempengaruhi kebijakan perusahaan dalam menyusun struktur modal perusahaan. Dengan kata lain, perusahaan dengan tingkat hutang USD yang tinggi akan cenderung mengurangi hutangnya ketika nilai tukar mata uang USD terhadap rupiah meningkat. Hal ini dapat menyebabkan manajemen perusahaan mengubah kebijakan struktur modalnya, dengan mengurangi hutang dalam bentuk USD tersebut.

Hasil penelitian menunjukan bahwa tidak ada pengaruh signifikan antara perubahan nilai tukar kurs USD terhadap rupiah. Hal ini dikarenakan, perusahaan manufaktur yang melakukan kegiatan ekspor akan mengalami peningkatan laba pada saat kurs USD terhadap rupiah menguat. Ketika kurs USD terhadap rupiah menguat, akan cenderung diikuti oleh adanya peningkatan penjualan ekspor. Selain itu, perusahaan yang melakukan kegiatan ekspor, akan cenderung memiliki aset lancar berupa kas dalam mata uang asing, seperti contohnya USD. Dengan adanya penguatan mata uang USD terhadap Rupiah, akan semakin banyak dana yang dapat diperoleh perusahaan, sehingga penggunaan hutang semakin kecil dan tidak memberikan pengaruh terhadap struktur modal perusahaan.

\section{KESIMPULAN}

Hasil penelitian empiris pada penelitian ini menunjukkan Profitabilitas (ROA), Tangibilitas (TAN), dan Pajak (TAX) berpengaruh negatif dan signifikan terhadap struktur modal (DER) perusahaan manufaktur yang terdaftar di Bursa Efek Indonesia periode 2016-2018. Sementara itu, Solvabilitas (DAR) berpengaruh positif, sedangkan variabel Likuiditas (CR), Sales Growth (SG), Inflasi, dan Kurs USD tidak berpengaruh terhadap struktur modal (DER) perusahaan manufaktur yang terdaftar di Bursa Efek Indonesia periode 2016-2018. Maka dari itu dapat disimpulkan bahwa terdapat pengaruh faktor internal maupun faktor eksternal terhadap Struktur Modal (DER) perusahaan.

\section{IMPLIKASI DAN KETERBATASAN}

Berdasarkan hasil penelitian yang
telah dilakukan maka penulis
menyampaikan beberapa saran sebagai
berikut (1) Bagi peneliti selanjutnya,
disarankan dapat menambah variabel
bebas lain yang mungkin berpengaruh
terhadap Struktur Modal perusahaan,
seperti misalnya ukuran perusahaan,
tingkat suku bunga SBI, risiko bisnis, Non
Debt Tax Shield, dan sebagainya
(2) Bagi investor, dengan adanya
penelitian ini diharapkan dapat
menurunkan tingkat risiko investasi yang
timbul dalam melakukan keputusan
investasi, dengan memperhatikan
fenomena atau faktor eksternal (Pajak)
sehingga investor dapat memprediksi
langkah apa yang akan diambil oleh pihak
manajer perusahaan.

(3) Bagi manajer perusahaan, dengan adanya penelitian ini diharapkan dapat 
menentukan komposisi struktur modal yang baik bagi perusahaan, dengan mempertimbangkan faktor-faktor eksternal maupun internal yang mempengaruhi struktur modal perusahaan.

\section{REFERENCES}

Angelya, Shelvy, and Erika Jimena Arilyn. 2017. "Faktor-Faktor Yang Mempengaruhi Struktur Modal Pada Perusahaan Industri Makanan Dan Minuman Yang Terdaftar Di Bursa Efek Indonesia." Jurnal Bisnis Dan Akuntansi 19(1a):313-19.

Ariyani, Hilma Faza, Irene Rini Demi Pangestuti, and Susilo Toto Raharjo. 2019. "The Effect Of Asset Structure, Profitability, Company Size, And Company Growth On Capital Structure (The Study of Manufacturing Companies Listed on the IDX for the Period 2013 - 2017)." Jurnal Bisnis Strategi 27(2):123.

Budiono, and Nur Septiani. 2017. "Profitabilitas Terhadap Struktur Modal Pada Perusahaan Lq-45 Yang Terdaftar Di Bursa Efek Indonesia Periode 2010-2015." Bisnis Manajemen 9(2):119-34.

Dewi, N., and I. Badjra. 2014. "Pengaruh Likuiditas, Profitabilitas, Tangibility Assets, Ukuran Perusahaan Dan Pajak Terhadap Struktur Modal.” E-Jurnal Manajemen Universitas Udayana 3(10):254248.

Firotun Hanafiyah, Ronny Malvia Mardani, Budi Wahono. 2018. "Prodi Manajemen.” (2011):155-65.

Hartono, J. (2013). Metodologi Penelitian Bisnis: Salah Kaprah dan Pengalaman-Pengalaman. Yogyakarta: BPFE.

Hery. (2015). Analisis Laporan Keuangan Pendekatan Rasio Keuangan.
Yogyakarta: CAPS (Center for Academic Publishing Service).

Van Horne, James C., and Jr. Wachowicz, John M. 2006. Fundamentals of Financial Management (13th Ed.). Cengage Learning.

Kaliman, Robert, and Satriyo Wibowo. 2017. "Pengaruh Ukuran Perusahaan, Risiko Bisnis, Growth ,Profitabilitas, Likuiditas, Dan Sales Growth Terhadap Struktur Modal Pada Sektor Farmasi Yang Terdaftar Di Bei." Jurnal Bisnis Dan Akuntansi 19(1a):185-90.

Lia Erosvitha, Cicilia, and Ni Wirawati. 2016. "Pengaruh Profitabilitas, Set Kesempatan Investasi, Pertumbuhan Penjualan Dan Risiko Bisnis Pada Struktur Modal." E-Jurnal Akuntansi 14(1):172-97.

Mai, Muhamad Umar. 2019. "Determinants of Capital Structure in Sharia Criteria Manufacturing Firms on the Indonesia Stock Exchange." Jurnal Keuangan Dan Perbankan 23(3):418-29.

Manajemen, Prodi, Oleh:. Alfiananda, Dwi Yulianto, Jeni Susyanti, and M. Agus Salim. 2019. E-Jurnal Riset Manajemen Pengaruh Inflasi, Suku Bunga Sbi, Tarif Pajak Dan Profitabilitas Terhadap Struktur Modal (Studi Kasus Pada Perusahaan Manufaktur Subsektor Logam Dan Sejenisnya Yang Terdaftar Di Bursa Efek Indonesia Selama Periode 2014-2017). Vol. 8.

Maryanti, Eny. 2016. "Analisis Profitabilitas, Pertumbuhan Perusahaan, Pertumbuhan Penjualan Dan Struktur Aktiva Terhadap Struktur Modal Pada Perusahaan Sektor Industri Barang Konsumsi Yang Terdaftar Di Bursa Efek Indonesia (Studi Empiris Pada 
Perusahaan Manufaktur Yang Terdaftar di Bursa Efek Indonesia (BEI)." Riset Akuntansi Dan Keuangan Indonesia 1(2):143-51.

Nirmala, Aulia, Moeljadi Moeljadi, and Andarwati Andarwati. 2016. "Pengaruh Ukuran Perusahaan, Profitabilitas, Pertumbuhan Penjualan Dan Kepemilikan Manajerial Terhadap Struktur Modal Dan Nilai Perusahaan Manufaktur Di Indonesia (Perspektif Pecking Order Theory)." Jurnal Aplikasi Manajemen 14(3):557-66.

Nita Septiani, Ni Putu, and I. Gusti Ngurah Agung Suaryana. 2018. "Pengaruh Profitabilitas, Ukuran Perusahaan, Struktur Aset, Risiko Bisnis Dan Likuiditas Pada Struktur Modal." EJurnal Akuntansi 22:1682.

Sari, Nurshadrina Kartika, Isti Fadah, and Hari Sukarno. 2017. "Determinan Struktur Modal Bank." EKUITAS (Jurnal Ekonomi Dan Keuangan) 17(1):71.

Subagyo, Herry. 2008. "Yang Dalam Penelitian Ini Diproksi Dengan Tingkat Inflasi, Tingkat Bunga Dan Pertumbuhan Ekonomi. Sedangkan Faktor Mikroekonomi Merupakan Faktor Yang Dapat Dikendalikan." 132-46.
Sugiyono. (2003). Statistika untuk Penelitian. Bandung: CV ALFABETA.

Suwardjono. (2005). Teori Akuntansi Perekayasaan Pelaporan Keuangan (Edisi Ketiga). Yogyakarta: BPFE.

Tanjung, Nasrullahi M. 2015. "Analisis Penggunaan Struktur Modal Dalam Kaitan Solvabilitas.” 3(4):207-14.

Wijayanti, Marsa Nurlita. 2018. "Pengaruh Variabel Makroekonomi Dan Mikroekonomi Terhadap Struktur Modal Perusahaan." Naskah Publikasi 1-10.

Yoshendy, Andi, Noer A. Achsani, and TB N. A. Maulana. 2016. "Analisis Faktor-Faktor Yang Mempengaruhi Struktur Modal Perusahaan Barang Konsumsi Di BEI Tahun 2002 2011." Jurnal Bisnis Dan Manajemen 16(1):47-59.

Yunita, Santi, and tony seno Aji. 2018. "Pengaruh Likuiditas, Tangibility, Growth Opportunity, Risiko Bisnis, Dan Ukuran Perusahaan Terhadap Struktur Modal." Jurnal Ilmu Manajemen 6:409-16. 